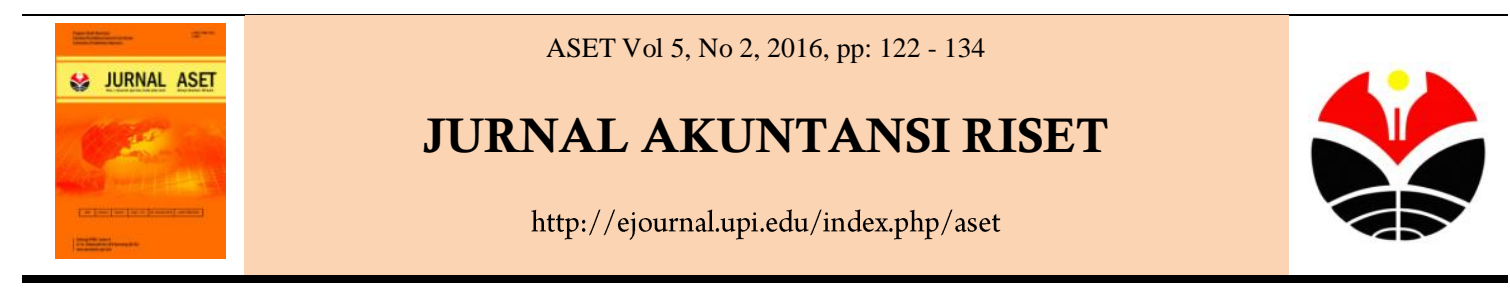

\title{
APLIKASI PENERIMAAN KAS DARI PEMBAYARAN PERPANJANGAN MEMBERSHIP BERBASIS KOMPUTER DI BATUNUNGGAL INDAH CLUB (BIC) BANDUNG
}

Eti Suprihatin ${ }^{1}$

STMIK \& Politeknik LPKIA. Bandung

Junaedi Abdillah ${ }^{2}$

STMIK \& Politeknik LPKIA. Bandung

Info Artikel Abstrak

Diterima : 18-08-2016

Direvisi : 29-08-2016

Diterbitkan : 18-09-2016

Keywords: Aplikasi; Kas; Membership;Batunungga I Indah Club.
Batununggal Indah Club (BIC) berdiri pada bulan April 2001 bergerak dalam penyediaan fasilitas olahraga dan ruang serbaguna yang berlokasi di kawasan komplek perumahan Batununggal Indah Bandung Selatan. Ada dua sistem transaksi pada Batununggal Indah Club terdiri dari keanggotaan (Membership) dan pengunjung umum (non Member) sebagai salah satu sumber penerimaan kas. Permasalahan terjadi saat pengelolaan pembayaran perpanjangan membership yang dikelola oleh bagian ADM Membership masih dilakukan secara manual, baik perhitungan, pembuatan faktur sampai Laporan Pembayaran Perpanjangan membership. Berdasarkan analisis permasalahan tersebut maka dibangun Aplikasi Penerimaan Kas dari Pembayaran Perpanjangan Membership dengan menggunakan Microsoft acces 2013. Metode penelitian yang digunakan waterfall yaitu melakukan pendekatan secara sistematis dan urut mulai dari level kebutuhan sistem sampai pemeliharaan sistem. Aplikasi ini diharapkan dapat menunjang kelancaran administrasi penerimaan kas pembayaran perpanjangan membership dan mengotomatisasi Laporan Penerimaan Kas Pembayaran Perpanjangan Membership

(C) Jurnal Akuntansi Riset. Program Studi Akuntansi. FPEB. UPI

Alamat korespondensi :

${ }^{1}$ Program Studi Komputerisasi Akuntansi STMIK \& Politeknik LPKIA Bandung

E-mail (ettysumadi@yahoo.com)

${ }^{2}$ Program Studi Komputerisasi Akuntansi STMIK \& Politeknik LPKIA Bandung

E-mail (junaedizalfa@gmail.com)
2541-0342 $2086-2563(\mathrm{cetak})$

\section{PENDAHULUAN}

Indah Club (BIC) yang pada awalnya bernama PT. Batununggal Indah Perkasa. Perusahaan ini berdiri pada bulan April 2001 perusahaan ini bergerak dalam penyediaan fasilitas olah raga dan ruang serbaguna yang berlokasi di kawasan komplek perumahan Batununggal di daerah Bandung Selatan. Konsep awal pendirian perusahaan ini merupakan upaya yang dilakukan 
pihak pengembang sekaligus pemilik PT. Batununggal Perkasa untuk membangun fasilitas olah raga di kawasan komplek perumahan Batununggal secara khusus dan penduduk Bandung secara umum. Ada dua sistem transaksi pada Batununggal Indah Club terdiri dari keanggotaan (Membership) dan pengunjung umum (non Member). Kebanyakan dari konsumen yang sering menggunakan Fasilitas olahraga pada sebuah sport center akan mengikuti program membership atau keanggotaan, karena lebih efisien bila dilihat dari segi harga. Transaksi membership dilakukan oleh bagian Administrasi Membership yang ditempatkan di Front Office, Selain melayani pelanggan dengan ramah juga harus bisa menangani transaksi membership seperti transaksi perpanjangan member dengan tepat, sebagai salah satu sumber penerimaan kas pada Batununggal Indah Club (BIC). Untuk pembayaran perpanjangan membership pada PT Batununggal Indah Club masih dilakukan secara manual, bukti transaksi masih ditulis tangan dan perhitungan masih dilakukan secara manual setelah itu diinputkan oleh Administrasi Membership menggunakan Microsoft Excel sebagai laporan transaksi harian sedangkan untuk jurnalnya sendiri dikerjakan terpisah oleh bagian kasir secara manual menggunakan Microsoft Excel. Hal ini dirasakan kurang efektif karena memerlukan waktu yang cukup lama dan mudah terjadinya kesalahan perhitungan.

Dengan melihat permasalahan tersebut, maka PT. Batununggal Indah Club memerlukan sebuah sistem administrasi penerimaan kas yang dapat mengatasi permasalahan transaksi membership secara cepat dan menghasilkan informasi akuntansi secara relevan. Untuk menangani permasalahan tersebut perlu dibangunnya suatu sistem yaitu " Aplikasi Penerimaan Kas Dari Pembayaran Membership Berbasis Komputer di PT. Batununggal Indah Club (BIC) Bandung”. Diharapkan aplikasi yang akan dibuat dapat membantu dalam meningkatkan kinerja manajerial pengelola PT. Batununggal Indah Club pada bagian Administrasi Penerimaan Kas Membership sehingga dapat menunjang kelancaran operasional Perusahaan

\section{KAJIAN LITERATUR}

Sistem Informasi Akuntansi - Krismiaji dalam bukunya yang berjudul Sistem Informasi Akuntansi Menyatakan bahwa "Sistem Informasi Akuntansi adalah sebuah sistem yang memproses data dan transaksi guna menghasilkan informasi yang bermanfaat untuk merencanakan, mengendalikan, dan dan mengoprasikan bisnis”. (2010:4)

Kemudian menurut James A. Hall dalam bukunya yang berjudul Accounting Information system, menyatakan bahwa "AIS subsistem procces financial transaction and nonfinancial transaction that directly affect the processing offinancial transaction”. (2011:7)

Robert G. Murdick, Thomas C. Fuller dan Joel E. Ross yang dikutip oleh Jogiyanto dalam bukunya yang berjudul "Analisis dan Desain Sistem Informasi: Pendekatan Terstruktur Teori dan Praktek Aplikasi Bisnis”, menyatakan bahwa: Sistem Informasi Akuntansi adalah kumpulan kegiatan-kegiatan dari organisasi yang bertanggung jawab untuk menyediakan informasi keuangan dan informasi yang didapatkan dari transaksi data untuk tujuan pelaporan internal kepada manajer untuk digunakan dalam pengendalian dan perencanaan sekarang dan 
operasi masa depan serta pelaporan eksternal kepada pemegang saham, pemerintah, dan pihakpihak luar lainnya. (2005:17)

Berdasarkan beberapa pendapat tersebut, dapat disimpulkan bahwa Sistem Informasi Akuntansi adalah sebuah sistem yang memproses data dan transaksi keuangan sehingga menghasilkan informasi yang berguna bagi pihak-pihak yang berkepentingan.

Dalam pengertian kas Soemarso S.R mengemukaan bahwa "Penerimaan Kas adalah suatu transaksi yang menimbulkan bertumbuhnya saldo kas dan Bank milik perusahaan yang dilakukan melalui penjualan hasil produksi, penerimaan piutang maupun hasil transaksi lainnya yang menyebabkan bertambahnya kas".( 2002: 172)

Mulyadi mengemukakan bahwa sistem akuntansi penerimaan kas adalah suatu catatan yang dibuat untuk melaksanakan kegiatan penerimaan uang dari penjualan tunai atau piutang yang siap dan bebas digunakan untuk kegiatan umum perusahaan. (2010:500).

$\mathrm{Ng}$ Eng Juan dan Ersa Triwahyuni mengemukakan bahwa kas pada umumnya terdiri atas saldo kas (cash on hand) dan rekening giro (cash in bank, termasuk overdrafbank). (2012:172)

Dapat disimpulkan bahwa penerimaan kas adalah suatu kegiatan pencatatan atas transaksi yang dapat menambah saldo kas baik yang ada di perusahaan maupun di bank.

Pengertian Database Management System (DBMS) menurut Andri Kristanto dalam bukunya yang berjudul "Perancangan Sistem Informasi dan Aplikasinya" menyatakan bahwa, "Manajemen Sistem Basis Data (Database Management System - DBMS) adalah perangkat lunak yang didesain untuk membantu dalam hal pemeliharaan dan utilitas kumpulan data dalam jumlah besar." (2008:79)

Basis Data - Mulyadi dalam bukunya "Sistem Akuntansi", menyatakan bahwa " Manajemen Sistem Basis Data (Database Management System DBMS) adalah program yang mengolah dan mengendalikan data Interface data dan program aplikasi” (2010:95) Salah satu contoh DBMS yaitu Mivrosoft Acces 2013.

Menurut Rosa A.S- M. Shalahuddin, DBMS (Database Management System) atau dalam bahasa Indonesia sering disebut sebagai Sistem Manajemen Basis Data adalah, "suatu sistem aplikasi yang digunakan untuk menyimpan, mengelola, dan menampilkan data". (Rosa A.S-M. Shalahuddin, 2011:45)

Dari beberapa pendapat tersebut dapat disimpulkan bahwa basis data adalah suatu sistem yang digunakan untuk mengelola data dari mulai mendesain input, mengelola penyimpanan dan menampilkan hasil berupa laporan data sesuai kebutuhan.

Pengertian Microsoft Access menurut Ashari dalam bukunya yang berjudul "Program Akuntansi untuk Usaha Dagang Menggunakan Microsoft Access", menyatakan bahwa 
"Aplikasi Microsoft Access adalah aplikasi untuk pengolahan data. Aplikasi ini merupakan aplikasi database yang memungkinkan pengguna untuk melakukan manipulasi data menggunakan fasilitas yang diberikan Microsoft Access." (2005:4)

Microsoft Access 2013 yang untuk selanjutnya disingkat Access 2013 adalah suatu program aplikasi basis data komputer relasional yang digunakan untuk merancang, membuat dan mengolah berbagai jenis data dengan kapasitas yang besar. Database adalah kumpulan tabeltabel yang saling berelasi. Antar tabel yang satu dengan yang lain saling berelasi, sehingga sering disebut basis data relasional. Relasi antar tabel dihubungkan oleh suatu key, yaitu primary key dan foreign key.

Microsoft Access 2013 - Haer Talib dalam bukunya yang berjudul "Panduan Lengkap Access 2013" menjelaskan bahwa "Sebuah software khusus untuk menyimpan dan mengelola data secara data base”. (2014:13)

Dapat disimpulkan bahwa Microsoft Access merupakan suatu aplikasi database untuk mendesain, membuat dan mengelola database sehingga menjadi sebuah tabel data yang saling berelasi.

\section{METODE PENELITIAN}

Dalam pengerjaan aplikasi ini metode yang digunakan yaitu sebagai berikut :

\section{METODE PENGUMPULAN DATA}

a. Wawancara

Pada tahapan ini dilakukan penelitian dengan mengadakan tanya jawab kepada bagian penerimaan kas yang bertanggung jawab atas segala transaksi penerimaan kas

b. Studi kepustakaan

Pada tahapan ini dilakukan pengumpulan data maupun informasi dengan membaca literatur atau menelaah buku-buku pedoman yang berkaitan dengan masalah dalam pembuatan aplikasi penerimaan kas.

c. Observasi

Pada tahapan ini melakukan pengumpulan data dengan mengadakan pengamatan langsung (observasi) atas kegiatan atau proses penerimaan kas terhadap objek yang dituju seperti bagian kasir dan keuangan.

\section{METODE PENGEMBANGAN SISTEM}

Dalam pembuatan aplikasi ini metode yang digunakan adalah System Development Life Cycle (SDLC) dengan model Waterfall yang berfungsi untuk menggambarkan tahapantahapan utama dan langkah-langkah dari setiap tahapan yang secara garis besar terbagi dalam beberapa fase. 
Menurut Jogiyanto (2005), terdapat 5 tahapan pada Waterfall Model, yaitu requirement analysis and definition, system and software design, implementation and unit testing, integration and system testing, dan operation and maintenance

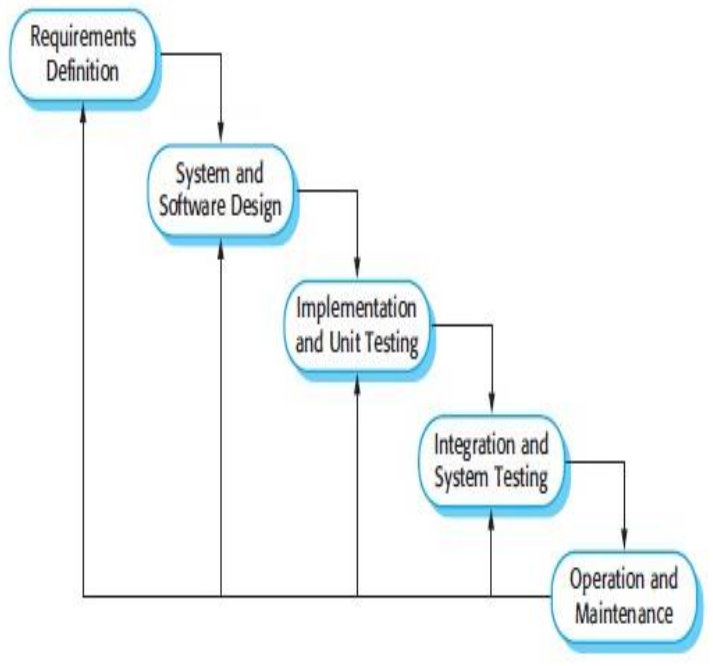

\section{a. Requirements and Definition}

Pada tahapan ini yang dilakukan adalah pengumpulan semua kebutuhan useryang berkaitan dengan perangkat lunak yang dibangun.

b. System and Software Design

Pada tahapan ini yang dilakukan adalah pembuatan DFD untuk menggambarkan pembagian sistem ke modul yang lebih kecil. Selanjutnya melakukan perancangan ERD (entity relationship diagram) untuk menggambarkan struktur logis dari basis data yang berbasis grafis.

c. Implementation and Unit Testing

Pada tahapan ini, melakukan pengujian terhadap aplikasi yang dibuat dikembang-kan.

d. Integration and System Testing

Dalam tahapan ini yang akan dilakukan yaitu setiap unit program akan diinte- grasikan satu sama lain dan diuji sebagai satu sistem yang utuh untuk memastikan sistem sudah memenuhi persyaratan yang ada. Setelah itu sistem akan dikirim ke pengguna sistem.

e. Operation and Maintenance

Dalam tahapan ini yang akan dilakukan penginstalan sistem dan mulai digunakan. Selain itu juga memperbaiki error yang tidak ditemukan pada tahap pembuatan. Dalam tahap ini juga dilakukan pengembangan sistem seperti penambahan fitur dan fungsi baru 


\section{HASIL DAN PEMBAHASAN}

\section{PROSEDUR SISTEM USULAN}

1. Bagian ADM Membership menerima kartu member dari member dan melakukan swap kartu pada aplikasi yang sudah ada untuk mengetahui masa berlaku kartu dan mengaktivasi kembali kartu member.

2. Bagian ADM Membership akan menginputkan transaksi perpanjangan kartu member dan mencetak sebanyak 3 rangkap secara otomatis mengunakan Ms Acces.

3. Faktur diberikan kepada member untuk di Ttd dan diambil untuk melakukan pembayaran di bagian Kassa.

4. Bagian Kassa akan menerima pembayaran sesuai jumlah transaksi dan menandatangani faktur sebagai bukti pelunasan.

5. Faktur lembar ke-1 akan diberikan kepada member beserta card, lembar ke- 2 diberikan kepada bagian ADM Membership dan lembar ke-3 oleh bagian Kassa beserta uang kas.

6. Bagian ADM Membership akan mencetak Laporan Transaksi Harian Perpanjangan Membership (LTHPM) secara otomatis menggunakan Ms Acces dan dilaporkan ke bagian Head marketing beserta bukti transaksi (Faktur lembar ke 2).

7. Head marketing akan memeriksa Laporan transaksi dengan faktur yang ada Dan melegalisir Laporan Tersebut.

8. Setelah di acc Faktur ke 2 dikembalikan dan akan diarsipkan oleh Bag ADM Membership.

Dari prosedur usulan Transaksi membership tersebut,yaitu sistem usulan mengotomatisasi bahkan sampai ke pembuatan Laporan harian transaksi dan faktur dengan tujuan untuk mempercepat Proses transaksi. 


\section{B. Mapping Chart Sistem Usulan}

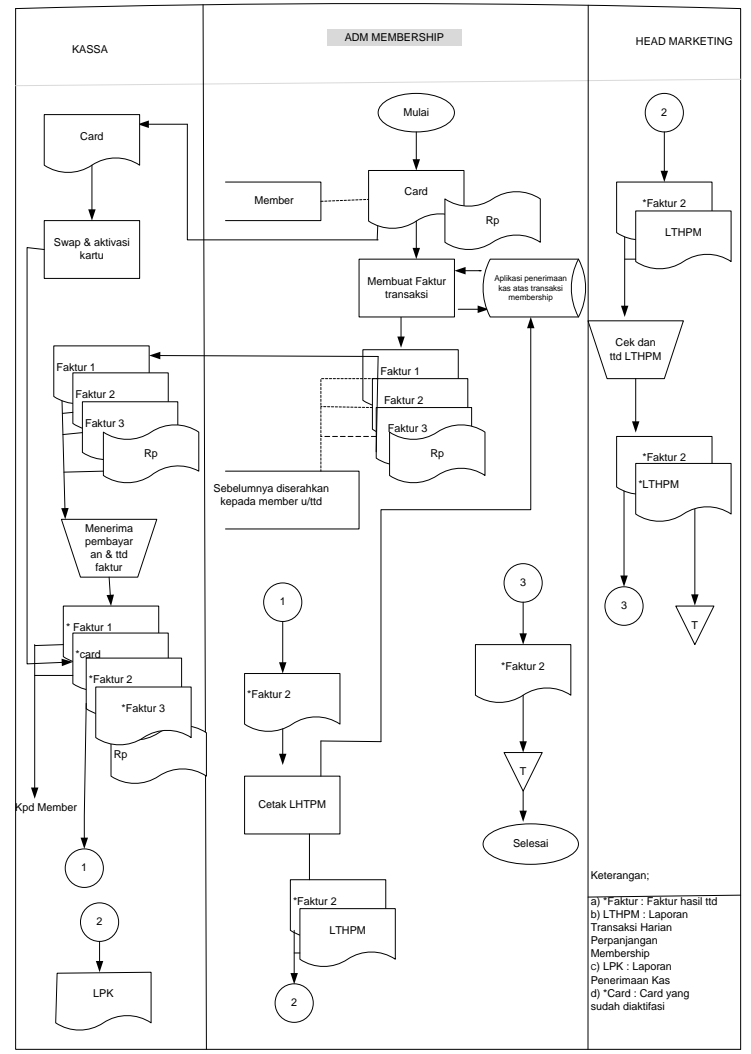

C. Context Diagram system usulan

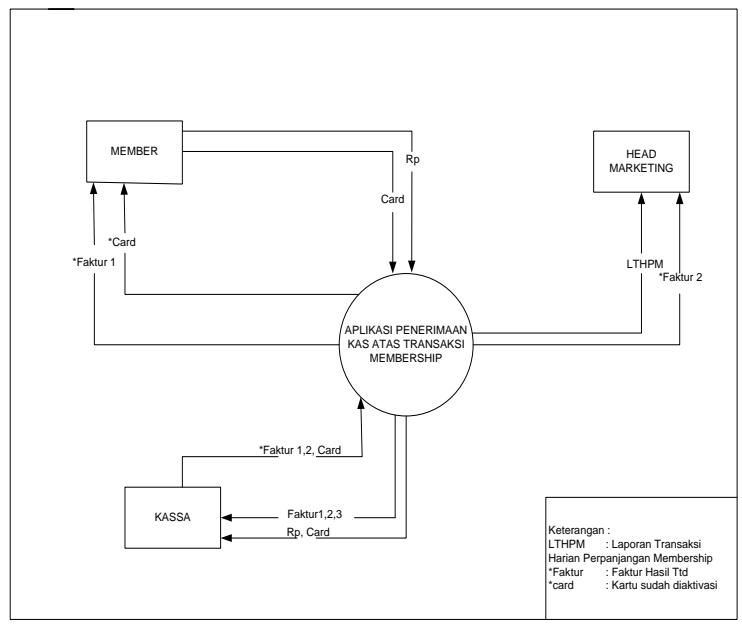

D. DFD level 0 Sistem Usulan 


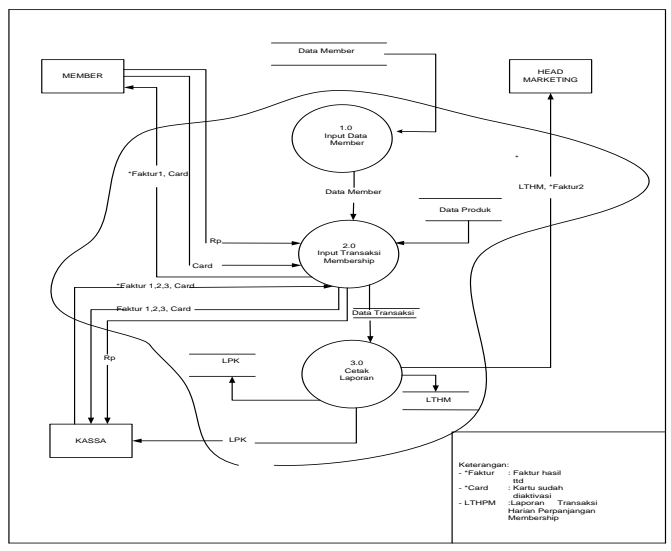

E. Data Dictionary

1) Kamus data Member

\begin{tabular}{|l|l}
\hline \multicolumn{2}{|c}{ Kamus Data Member } \\
\hline Nama & Member \\
\hline Penelitian & $\begin{array}{l}\text { Informasi Mengenai } \\
\text { Member }\end{array}$ \\
\hline Struktur Data & $\begin{array}{l}\text { No member + kartu mer } \\
+ \text { Nama + Alamat + } \\
\text { Telepon + Periode Aw } \\
\text { Periode Akhir }\end{array}$ \\
\hline No member & $\{$ A-Z $\}\{0-9\}$ \\
\hline Kartu member & $\{$ A-Z $\}\{$ a-Z $\}$ \\
\hline Nama & $\{$ A-Z $\}\{$ a-Z $\}$ \\
\hline Alamat & $\{$ a-z $\}\{$ A-Z $\}\{0-9\}$ \\
\hline No Telepon & $\{0-9\}$ \\
\hline Periode Awal & Date/time \\
\hline Periode Akhir & Date/time \\
\hline
\end{tabular}

2) Kamus Data Produk

\begin{tabular}{|c|c|}
\hline \multicolumn{2}{|c|}{ Kamus Data Produk } \\
\hline Nama & Produk \\
\hline Deskripsi & $\begin{array}{l}\text { Informasi mengenai } \\
\text { tentang Data Produk }\end{array}$ \\
\hline Struktur Data & $\begin{array}{l}\text { Kode Produk + Nama } \\
\text { Produk + Harga }\end{array}$ \\
\hline Kode Produk & $\{A-Z\}$ \\
\hline Nama Produk & $\{a-z\}\{A-Z\}$ \\
\hline Harga & $\{0-9\}$ \\
\hline
\end{tabular}

3) Kamus Data Head Transaksi 


\begin{tabular}{|l|l|}
\hline \multicolumn{2}{|c|}{ Kamus Data Head } \\
\hline Nama & Head Transaksi \\
\hline Deskripsi & $\begin{array}{l}\text { Informasi mengenai } \\
\text { Laporan Transaksi } \\
\text { Harian Membership }\end{array}$ \\
\hline $\begin{array}{l}\text { Struktur } \\
\text { Data }\end{array}$ & $\begin{array}{l}\text { No Faktur + Tanggal + } \\
\text { No Member + Total + } \\
\text { PPN + Jumlah bayar + } \\
\text { Periode Awal + Periode } \\
\text { Akhir }\end{array}$ \\
\hline No Faktur & $\{0-9\}$ \\
\hline Tanggal & Date/Time \\
\hline No Member & $\{$ A-Z $\{0-9\}$ \\
\hline Total & $\{0-9\}$ \\
\hline PPN & $\{0-9\}$ \\
\hline Jumlah byr & $\{0-9\}$ \\
\hline
\end{tabular}

4) Kamus Data Laporan Transaksi Harian

\begin{tabular}{|l|c|l|}
\hline \multicolumn{3}{|c|}{ Kamus Data } \\
\hline Nama & $:$ & $\begin{array}{l}\text { Laporan Transaksi } \\
\text { Harian }\end{array}$ \\
\hline Deskripsi & $:$ & $\begin{array}{l}\text { Informasi mengenai } \\
\text { Laporan Transaksi } \\
\text { Harian }\end{array}$ \\
\hline Struktur Data & $:$ & $\begin{array}{l}\text { No+ no faktur + No } \\
\text { member +Nama + } \\
\text { Harga + Periode } \\
+ \text { Periode Awal + } \\
\text { Periode Akhir+ } \\
\text { Subotal +PPN + } \\
\text { Jumlah bayar }\end{array}$ \\
\hline No & & $\{0-9\}$ \\
\hline No Faktur & & $\{0-9\}$ \\
\hline No Member & $:$ & $\{$ A-Z $\{0-9\}$ \\
\hline Nama & $:$ & $\{a-z\}\{$ A-Z $\}$ \\
\hline Harga & $:$ & $\{0-9\}$ \\
\hline Periode & $:$ & $\{0-9\}$ \\
\hline Total & $:$ & $\{0-9\}$ \\
\hline PPN & $:$ & $\{0-9\}$ \\
\hline Jumlah Bayar & $:$ & $\{0-9\}$ \\
\hline
\end{tabular}




\section{IMPLEMENTASI}

\section{A. Dialog Screen}

Nama : Menu Utama

Fungsi : Tampilan utama program

Bentuk :

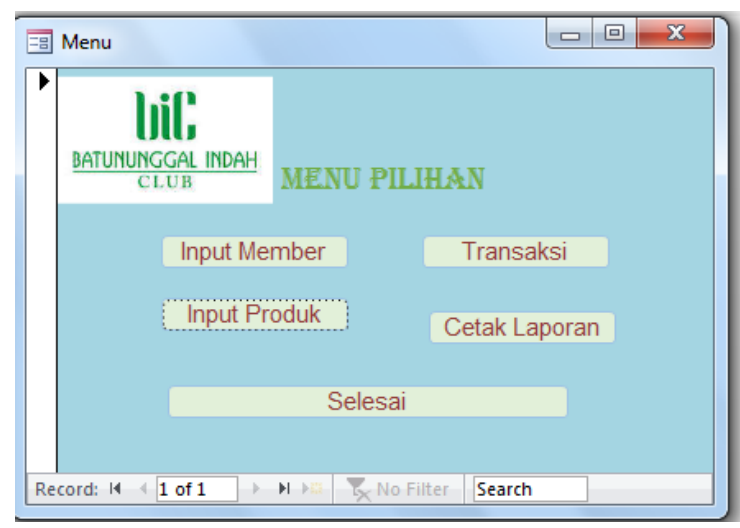

Nama : Menu Member

Fungsi : Tampilan untuk menginput data member baru Bentuk:

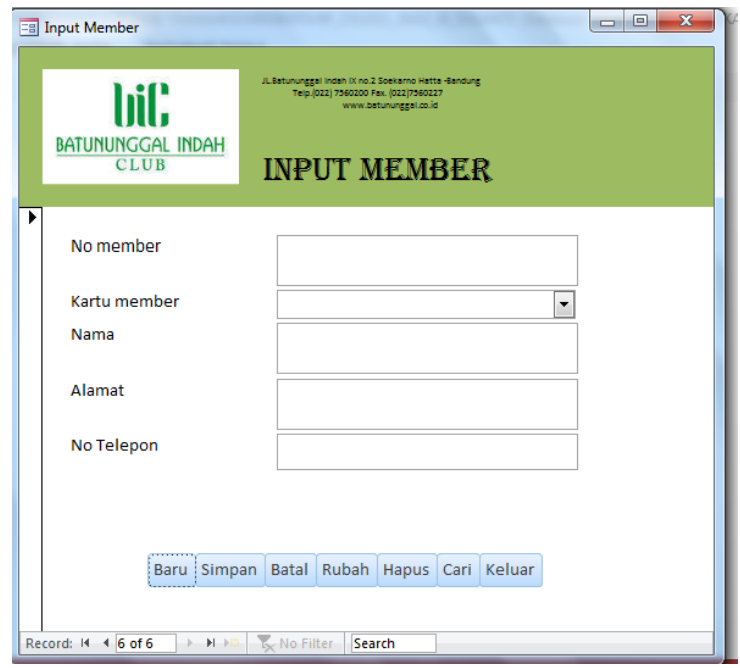

Nama : Menu Produk 
Fungsi : Tampilan untuk menginput data Produk member

Bentuk:

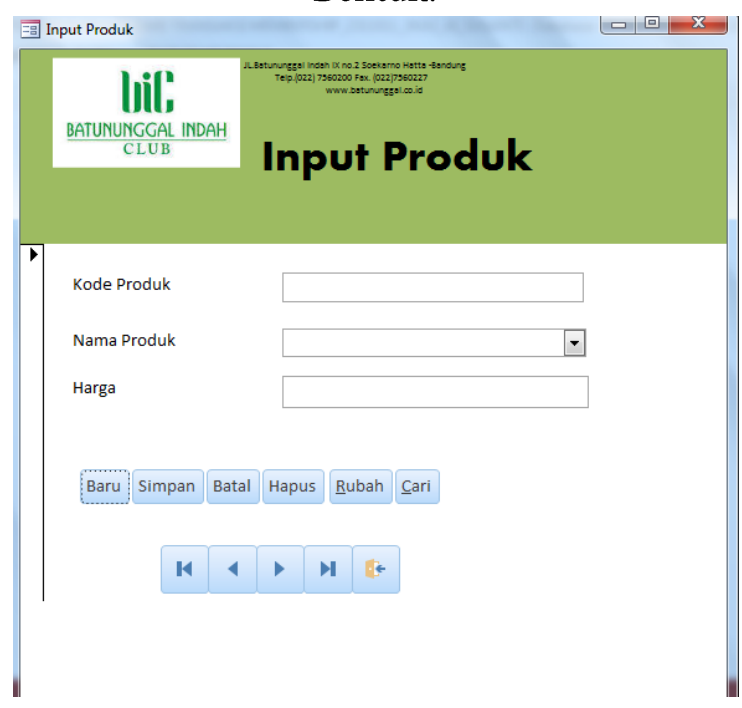

Nama : Menu Transaksi

Fungsi : Tampilan untuk menginput hasil Transaksi

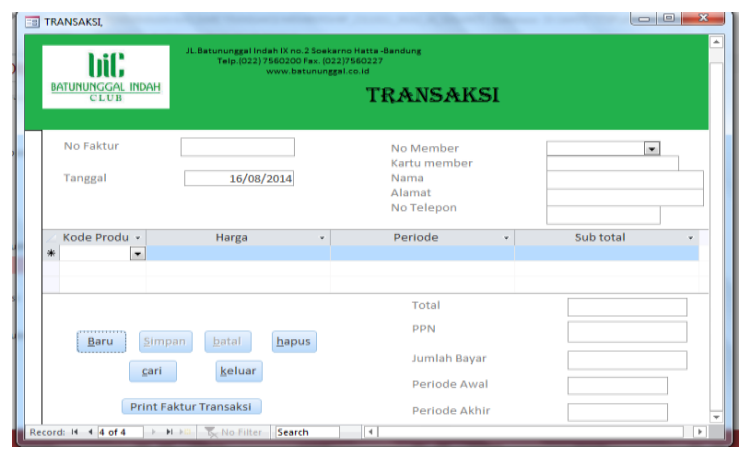

Nama : Menu Laporan

Fungsi : Menampilkan Laporan

Bentuk:

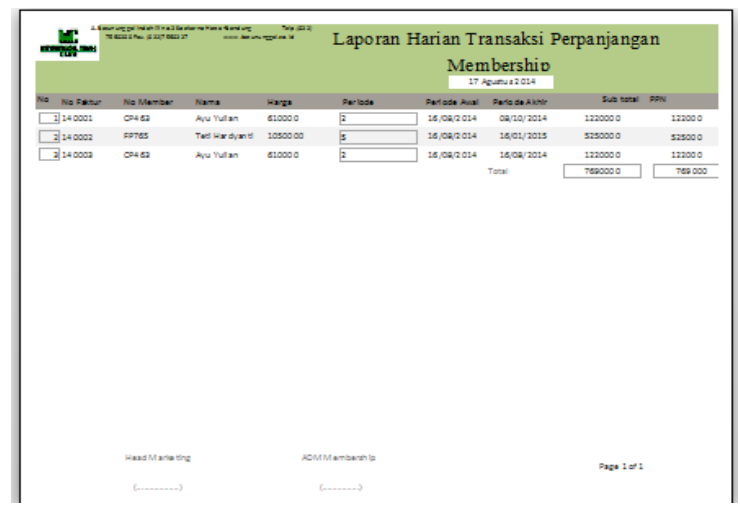




\section{SIMPULAN DAN SARAN}

\section{KESIMPULAN}

Pada penelitian ini dapat ditarik simpulan sebagai berikut:

1. Aplikasi Penerimaan Kas dari Transaksi Perpanjangan Membership sudah dapat menangani pengelolaan bukti Transaksi dengan baik

2. Aplikasi Penerimaan Kas dari Transaksi Perpanjangan Membership sudah dapat memproses perhitungan penerimaan kas dari Transaksi Perpanjangan membership dengan baik

3. Aplikasi ini sudah dapat menyajikan laporan transaksi Perpanjangan membership secara otomatisasi.

\section{SARAN}

Pada penelitian ini dapat ditarik saran sebagai berikut:

1. Aplikasi Penerimaan Kas dari transaksi Perpanjangan Membership di Batununggal Indah Club (BIC) bisa ditambahkan untuk menangani transaksi Member baru, Cuti dan pengembalian Deposit Kartu

2. Aplikasi Penerimaan Kas dari transaksi Perpanjangan Membership di Batununggal Indah Club (BIC) Sebaiknya Untuk pengembangannya ditambahkan Output Berupa Jurnal dan Buku Besar.

\section{DAFTAR PUSTAKA}

Ali, M. (2014). Memahami Riset Pelaku dan Sosial. Bandung: Bumi Aksara.

A.S Rosa dan M. Shalahuddin. 2011. Modul Pembelajaran Rekayasa Perangkat Lunak

(Terstruktur dan Berorientasi Objek). Bandung: Modula.

Ashari, SE. Akt. 2005. Program Akuntansi untuk Usaha Dagang Menggunakan Microsoft

Access. Jakarta: PT. Elex Media Komputindo.

H Kusnadi, 2000. Akuntansi Keuangan Menengah (Intermediate)

Haer Talib, 2014. Paduan Lengkap Acces 2013. Jakarta : Elex Media Komputindo

IAI (Ikatan Akuntansi Indonesia) PSAP Nomor 3.

James A Hall, 2001. Sistem Informasi Akuntansi. Edisi Satu. Jakarta: Salemba

Empat.

Jogiyanto. 2005. Analisis dan Desain Sstem Informasi: Pendekatan Terstruktur Teori dan

Praktek Aplikasi Bisnis. Yogyakarta: Andi Offset.

Krismiaji, 2010.Sistem Informasi Akuntansi. Yogyakarta: UPP STIM YPKN.

Kristanto, Andri. 2008. Perancangan Sistem Informasi dan Aplikasinya. Yogyakarta: Gava Media. 
Mangkulo, Hengky Alexander . 2010, Microsoft Acces 2010 untuk Pemula Cara

Cepat dan Mudah Menguasai Ms. Acces 2010, Jakarta : PT Elex Media Komputindo Mulyadi, 2010. Sistem Akuntansi. Jakarta : Salemba Empat.

Ng Eng Juan dan Ersa Triwahyuni. 2012. Panduan Praktis Standar Akuntansi Keuangan Berbasis IFRS. Edisi 2. Salemba Empat.

Puspitawati, Lilis dan Sri Dewi Anggadini, 2011. Sistem Informasi Akuntansi. Edisi Pertama Yogyakarta: Graha Ilmu

Rudianto, 2012. Pengantar Akuntansi. Jakarta : Erlangga

Soemarso SR, 2002. Akuntansi Suatu Pengantar. Jakarta : Salemba Empat. 